\title{
PIDANA PEMBAYARAN UANG PENGGANTI: DULU KINI DAN MASA DATANG
}

\author{
Akhiar Salmi ${ }^{1}$
}

\begin{abstract}
Abstrak
This article gives comparison implementation of alternate payment 'uang pengganti'. Assessment between the criminal provisions of the alternate payment that have been regulated by Law No. 31 of 1999 with prior Law No. 3 of 1971 so there is a divergence. According to Law No. 3 of 1971 for convicts who are unable to pay the applicable provisions replacement of the fines, the maximum jail sentence is replaced with a substitute. Meanwhile, according to Law No. 31 of 1999 offender will be punished with imprisonment, shall not exceed the maximum principal penalty. It could be argued that Law No. 31 of 1999 introduces a replacement imprisonment that has not been there. So far only known substitute for criminal confinement. Any how the author is still questioning on effectiveness the provisions of Article 18 paragraph (3) of Law No. 31 of 1999 to eradicate corruption practice.
\end{abstract}

Kata kunci:hukum pidana, pidana, pembayaran, uang pengganti

\section{Pendáhuluan}

Pidana pembayaran uang pengganti yang dibahas dalam tulisan ini adalah apa yang telah diatur dan sebaiknya diatur oleh peraturan tindak pidana korupsi masa datang. Harapan dari tulisan ini adalah agar kita memberikan perhatian yang lebih besar pada pidana pembayaran uang pengganti dalam rangka mengembalikan uang Negara yang sudah dikorup oleh koruptor. Sampai saat ini pidana pembayaran uang pengganti masih berupa pidana tambahan. Jadi tidak wajib dituntut oleh penuntut umum dan tidak wajib pula diputus oleh hakim.

Tindak pidana korupsi sangat merugikan keuangan dan perekonomian negara, sehingga menghambat pembangunan nasional. Akibat selanjutnya adalah sulit untuk memajukan kesejahteraan umum yang merupakan salah satu tujuan Negara Republik Indonesia sebagaimana tertuang dalam

${ }^{1}$ Penulis adalah Staf Pengajar Fakultas Hukum Universitas Indonesia. Alamat korespondensi: suparman61@ui.ac.id 
Pembuakaan Undang-Undang Dasar 1945. Bahkan lebih jauh tindak pidana korupsi bisa menghancurkan bangunan masyarakat. Oleh karena itu tindak pidana korupsi haruslah diberantas, paling tidak dikurangi.

Tindak pidana korupsi merupakan tindak pidana terhadap harta benda atau kekayaan, dalam hal ini harta benda yang merupakan kekayaan negara. Sehingga yang menderita kerugian adalah negara. Oleh karena itu yang utama dalam pemberantasan tindak pidana korupsi adalah mengembalikan uang yang dikorupsi. Namun demikian, tidak berarti jenis-jenis pidana yang lain tidak penting dalam pemberantasan tindak pidana korupsi.

\section{Pengaturan Dalam Perundang-undangan}

Dalam memberikan gambaran yang lebih utuh terhadap pidana pembayaran uang pengganti, maka perlu memaparkan sekilas tentang sejarah pengaturannya dari dulu sampai saat ini. Juga untuk lebih mudah mengetahui tentang bagaimana bunyi aturannya, maka akan dikutipkan bunyi Pasalnya, termasuk penjelasan Pasal tersebut.

Jenis pidana pembayaran uang pengganti pertama kali diperkenalkan dan diatur oleh Peraturan Penguasa Militer Nomor Prt/PM/06/1957 Kepala Staf Angkatan Darat Seleku Penguasa Militer Atas daerah Angkatan Darat Di Seluruh Wilayah Indonesia tanggal 9 April 1957 tentang Pemberantasan Korupsi. Pasal 25-nya berbunyi:

\section{Barang siapa melakukan korupsi dihukum dengan hukuman penjara selama-lamanya 5 tahun, segala harta benda yang diperoleh dari korupsi itu di rampas atau diwajibkan membayar uang pengganti sejumlah sama dengan harta benada yang diperoleh dari korupsi.}

Peraturan tersebut hanya memiliki penjelasan umum, tidak ada penjelasan Pasal demi Pasal karena dipandang sudah cukup jelas. Di dalam penjelasan umum tidak ada disinggung mengenai tata cara pelaksanaan pidana pembayaran uang pengganti dan juga tidak diatur mengenai akibat dari tidak dilaksanakannya pidana pembayaran uang pengganti tersebut oleh terpidana. Jadi, pengaturannya sangat sumir, tidak lengkap. Walaupun tidak lengkap, tapi tetap merupakan tonggak sejarah yang pertama mengatur jenis pidana pembayaran uang pengganti dalam rangka memberantas korupsi.

Peraturan Penguasa Perang Pusat Nomor Prt/Peperpu/ 013/1958 tanggal 16 April 1958 tentang Pengusutan, Penuntutan Dan Pemeriksaan Perbuatan Korupsi Pidana Dan Penilikan Harta Benda, dikeluarkan oleh 
Kepala Staf Angkatan Darat Selaku Penguasa Perang Pusat Untuk Daerah Angkatan Darat sebagai pengganti dari Peraturan Penguasa Militer Nomor Prt/PM/06/1957 tanggal 9 April 1957. Ketentuan pidana pembayaran uang pengganti diatur dalam Pasal 40 (3) yang berbunyi, "Siterhukum dapat juga diwajibkan membayar uang pengganti yang jumlahnya sama dengan harta benda yang diperoleh dari korupsi".

Apabila diperbandingkan bunyi Pasal dari dua peraturan di atas maka pidana pembayaran uang pengganti yang diatur oleh Peraturan Penguasa Perang Pusat Nomor Prt/Peperpu/013/1958 tanggal 16 April 1958 adalah sama dengan Peraturan Penguasa Militer Nomor Prt/PM/06/1957 tanggal 9 April 1957, tidak lengkap. Oleh karena itu sulit untuk diaplikasikan serta menimbulkan banyak pertanyaan ketika hendak melaksanakannya. Antara lain, bagaimana kalau terpidana tidak membayar uang pengganti dengan suka rela, upaya hukum apa yang dapat ditempuh oleh negara? Padahal, salah satu maksud dari Peraturan Penguasa Perang Pusat Nomor Prt/Peperpu/013/1958 tanggal 16 April 1958 adalah untuk menyempurnakan Peraturan Penguasa Militer Nomor Prt/PM/06/1957 tanggal 9 April 1957. Hal ini dapat dibaca dalam konsiderannya huruf a, yang berbunyi:

\begin{abstract}
Bahwa untuk perkara-perkara pidana yang menyangkut keuangan negara atau daerah atau badan hukum lainnya yang mempergunakan modal dan atau kelonggaran-kelonggaran lainnya dari masyarakat misalnya bank, koperasi, wakap dan lain-lain atau yang bersangkutan dengan kedudukan si pembuat pidana, perlu diadakan tambahan beberapa aturan pidana, pengusutan, penuntutan dan pemeriksaan yang dapat memberantas perbuatan-perbuatan yang disebut perbuatan korupsi.
\end{abstract}

Pada tanggal 17 April 1958 Kepala Staf Angkatan Laut Selaku Penguasa Perang Pusat Laut mengeluarkan Surat Keputusan Kepala Staf Angkatan Laut Nomor Z.1/1/7 tentang Peraturan tentang Pengusutan, Penuntutan dan Pemeriksaan Perbuatan Korupsi pidana dan Penilikan Harta Benda. Isinya sama dengan Peraturan Penguasa Perang Pusat Nomor Prt/Peperpu/013/1958 yang dikeluarkan oleh Kepala Staf Angkatan Darat, sehingga persoalannya tentu juga sama. Ketentuan pidana pembayaran uang pengganti juga diatur dalam Pasal 40 (3) yang berbunyi, "Siterhukum dapat juga diwajibkan membayar uang pengganti yang jumlahnya sama dengan harta benda yang diperoleh dari korupsi”.

Semula peraturan tentang pemberantasan korupsi, in casu, pidana pembayaran uang pengganti, belum diatur dalam undang-undang 
sebagaimana terlihat dalam tiga peraturan di atas. Akhirnya pada tahun 1960 baru diatur dalam undang-undang, yaitu melalui Peraturan Pemerintah Pengganti Undang-undang Nomor 24 tahun 1960 tanggal 9 Juni 1960 yang oleh undang-undang Nomor 1 tahun 1961 ditetapkan menjadi undangundang dan disebut Undang-undang Nomor 24 Prp. Tahun 1960 tentang Peraturan Pemberantasan Korupsi. Ketentuan pidana pembayaran uang pengganti diatur dalam Pasal 16 (3), yang berbunyi "Siterhukum dapat juga diwajibkan membayar uang pengganti yang jumlahnya sama dengan harta benda yang diperoleh dari korupsi”.

Persoalan pidana pembayaran uang pengganti dalam Undang-undang Nomor 24 Prp. tahun 1960 sama dengan peraturan-peraturan terdahulu. Bahkan bunyi Pasal 16 (3) Undang-undang Nomor 24 Prp. tahun 1960 persis sama redaksinya dengan Pasal 40 (3) Peraturan Penguasa Perang Pusat Nomor Prt/Peperpu/013/1958. Penjelasan Pasal 16 Undang-undang Nomor 24 Prp. tahun 1960 yang dimuat dalam Tambahan Lembaran Negara Republik Indonesia Nomor 2011 hanya mengatakan, "Periksa penjelasan mengenai Pasal 1". Penjelasan Pasal 1 juga tidak menyinggung mengenai penjelasan tentang pidana pembayaran uang pengganti. Oleh karena itu, sulit diharapkan korupsi bisa diberantas melalui penerapan pidana pembayaran uang pengganti semasa berlakunya Undang-undang Nomor 24 Prp. tahun 1960.

Berhubung karena Undang-undang Nomor 24 Prp. tahun 1960 kurang cukup untuk dapat mencapai hasil yang diharapkan, maka undang-undang tersebut diganti dengan Undang-undang Nomor 3 tahun 1971 tentang Pemberantasan Tindak Pidana Korupsi pada tanggal 29 Maret 1971. Pidana pembayaran uang pengganti tetap dipertahankan dan diatur dalam Pasal 34 huruf $\mathrm{c}$ yang berbunyi, Pembayaran uang pengganti yang jumlahnya sebanyak-banyaknya sama dengan harta benda yang diperoleh dari korupsi.

Sekilas Pasal 34 c Undang-undang Nomor 3 tahun 1971 sama dengan Pasal 16 (3) Undang-undang Nomor 24 Prp. tahun 1960, namun apabila dilihat penjelasan Pasal 34, maka tampaklah perbedaannya. Ada suatu kemajuan, yaitu solusi terhadap terpidana yang tidak dapat memenuhi pidana pembayaran uang pengganti maka diberlakukan ketentuan tentang pelaksanaan pembayaran pidana denda. Lengkapnya penjelasan Pasal 34 Undang-undang Nomor 3 tahun 1971 yang dimuat dalam Tambahan Lembaran Negara Nomor 2958 berbunyi:

Apabila pembayaran uang pengganti tidak dapat dipenuhi oleh terdakwa maka berlakulah ketentuan-ketentuan mengenai pelaksanaan pembayaran hukuman denda. 
Ketentuan tentang pidana denda diatur dalam Pasal 30 sampai dengan Pasal 31 KUHP. Menurut Pasal 30 (1) KUHP, "Jika denda tidak dibayar, lalu diganti dengan kurungan" dan kurungan pengganti paling sedikit satu hari dan paling lama enam bulan serta tidak boleh lebih dari delapan bulan, vide Pasal 30 (2) sampai dengan (6).

Penerapan pelaksanaan denda kedalam pidana pembayaran uang pengganti, tidaklah tepat dan menimbulkan masalah hukum yang serius. Antara lain mengkompensasikan jumlah pidana pembayaran uang pengganti ke dalam lamanya kurungan pengganti yang maksimal delapan bulan. Misalnya terpidana dijatuhi pidana pembayaran uang pengganti satu triliyun rupiah dan cara penghitungan lamanya pidana kurungan pengganti di dasarkan atas ketentuan Pasal 30 (4) KUHP. Pasal 30 (4) KUHP berbunyi:

\begin{abstract}
Dalam putusan hakim lamanya kurungan pengganti ditetapkan demikian: Jika dendanya lima puluh sen atau kurang, dihitung satu hari; jika lebih dari lima puluh sen, tiap-tiap lima puluh sen dihitung paling banyak satu hari demikian pula sisanya yang tidak cukup lima puluh sen.
\end{abstract}

Melalui Peraturan Pemerintah Pengganti Undang-undang Nomor 18 tahun 1960 ditetapkan bahwa denda harus dibaca dalam mata uang rupiah dan dilipat gandakan menjadi lima belas kali. $^{2}$ Walupun sudah dilipat gandakan sebanyak lima belas kali lipat maka tetap akan melebihi ketentuan Pasal 30 (3) KUHP yang menetapkan maksimal kurungan pengganti selama enam bulan dan bahkan bisa meliwati angka delapan bulan yang merupakan batas maksimal dari pidana kurungan pengganti yang dimungkinkan oleh Pasal 30 (6) KUHP. Jika jumlah satu triliyun rupiah hanya diganti dengan pidana kurungan pengganti selama enam bulan maka sangat tidak tepat dan akan menyinggung rasa keadilan masyarakat. Dengan demikian, tujuan pemidanaan tidak akan tercapai dan korupsi tetap akan merajalela.

Undang-undang Nomor 31 tahun 1999 menggantikan Undang-undang Nomor 3 tahun 1971 dan ketentuan pidana pembayaran uang pengganti diatur dalam Pasal 18 (1) b jo ayat (2) jo ayat (3). Bunyi Pasal 18 adalah:

(1) b. pembayaran uang pengganti yang jumlahnya sebanyakbanyaknya sama dengan harta benda yang diperoleh dari tindak pidana korupsi.

${ }^{2}$ E. Utrecht, "Hukum Pidana II", (Surabaya: Pustaka Tinta Mas, 1987), hal. 316 - 
(2) Jika terpidana tidak membayar uang pengganti sebagaiman dimaksud dalam ayat (1) huruf b paling lama dalam waktu 1 (satu) bulan sesudah putusan pengadilan yang telah memperoleh kekuatan hukum tetap, maka harta bendanya dapat disita oleh jaksa dan dilelang untuk menutupi uang pengganti tersebut.

(3) Dalam hal terpidana tidak mempunyai harta benda yang mencukupi untuk membayar uang pengganti sebagaimana dimaksud dalam ayat (1) huruf $b$, maka dipidana dengan pidana penjara yang lamanya tidak melebihi ancaman maksimum dari pidana pokoknya sesuai dengan ketentuan dalam Undang-undang ini dan lamanya pidana tersebut sudah ditentukan dalam putusan pengadilan.

Penjelasan Pasal 18 ayat (1) b; ayat (2) dan ayat (3) mengatakan cukup jelas.

Jika dibandingkan antara ketentuan pidana pembayaran uang pengganti yang diatur oleh Undang-undang Nomor 31 tahun 1999 dengan Undang-undang Nomor 3 tahun 1971 maka terdapat perbedaan. Kalau menurut Undang-undang Nomor 3 tahun 1971 bagi terpidana yang tidak mampu membayar uang pengganti maka berlaku ketentuan tentang denda, yaitu diganti dengan pidana kurungan pengganti. Sedangkan menurut Undang-undang Nomor 31 tahun 1999 akan dipidana dengan pidana penjara, maksimumnya tidak boleh melebihi pidana pokok. Dapat dikatakan bahwa Undang-undang Nomor 31 tahun 1999 mengintrodusir pidana penjara pengganti yang selama ini belum pernah ada. Selama ini baru dikenal pidana kurungan pengganti. Apakah ketentuan Pasal 18 ayat (3) Undang-undang Nomor 31 tahun 1999 akan efektif untuk memberantas tindak pidana korupsi? Tentu waktulah yang akan membuktikan.

Kelihatannya ketentuan pidana pembayaran uang pengganti yang diatur dalam Undang-undang Nomor 31 tahun 1999 lebih memberi arah yang jelas dan kepastian untuk dilaksanakan. Tahap-tahap yang akan ditempuh sudah terarah, tinggal bagaimana melaksanakannya saja. Walaupun demikian, alangkah lebih baik kiranya apabila penyitaan terhadap harta benda terpidana diletakan sedari awal, sejak ia masih berstatus tersangka. Tidak seperti yang diatur oleh Pasal 18 ayat (2) Undang-undang Nomor 31 tahun 1999, sita baru bisa diletakan setelah meliwati tenggang waktu satu bulan sejak putusan pengadilan memperoleh kekuatan hukum tetap. Jarak waktu satu bulan bukanlah sebentar, banyak hal-hal yang bisa terjadi, antara lain terpidana memindah tangankan hartanya kepada pihak ketiga lainnya atau menyembunyikannya. Jika ini terjadi maka hakekat pidana pembayaran uang pengganti tidak tercapai, yaitu untuk mengembalikan uang negara. Oleh 
karena itu ketentuan pidana pembayaran uang pengganti dalam Undangundang Nomor 31 tahun 1999 masih tetap perlu disempurnaklsat.

Undang-undang Nomor 31 tahun 1999 diiundangkan pada tanggal 16 Agustus 1999 dan kemudian timbul polemïk tentang Ikeberadaan Undangundang Nomor 3 tahun 1971. Polemik muncul lkanena Undang-undang Nomor 3 tahun 1971 dinyatakan tidak berlaku oleh Pasal 44 Undang-undang Nomor 31 tahun 1999. Ada yang berpendapat bahwa Undang-undang Nomor 3 tahun 1971 masith tetap berlaku dan dapat digunakan untuk menghukum pelaku tindak pidana konupsi yang melakukan tivdak pidana konupsi selbelum tanggal 16 Agustus 1999. Dasannya adalah Pasal 11 ayat (2) KUHP. Akan tetapi, ada pula yang berpendapat bahwa Undang-undang $\mathbb{N}$ omor 3 tahun 1971 tidak dapat lagi digunakan untuk menjerat pelaku tindak pidana konupsi yang melakukan tindak pidana korupsi sebelum tanggal 16 Agustus 1999 karena sudah dicabut oleh Undang-undang Nomor 31 tabun 1999 melalui Pasal 44 dan Undang-undang Nomor 31 talhun 1999 tidak memuat aturan peralihaan. Dengan demikian pelaku tindak pidana lkonupsi yaang melakukan tindak pidana konupsi sebelum tanggal 16 Agustus 1999 tidak dapat dituntut ke pengadilan karena "Ada semacam "dekriminallisasi" terthadap segala perbuatan pidana yang terjadi dimasa Undang-undang $\mathbb{N}$ omor $3 / 1971$. 3

Polemik tersebut berakhir dengan diundangkannya Undang-undang Nomor 20 tahun 2001 pada tanggal 21 Nopember 2001 tentang Penubahan Atas Undang-undang Nomor 31 tabun 1999 tentang Pewberantasan Tindak Pidana Konupsi. Pasal 43A ayat (1) Undang-undang Nomor 20 tahun 2001 menyatakan bahwa Undang-undang Nomor 3 Talbun 1971 tetap berlaku terhadap tindak pidana konupsi yang terjadi sebelum UUndang-undang Nomor 31 Talhun 1999 diundangkan. Penjelasan umum Urndang-undang Nomor 20 tahun 2001 mengatakan bahwa "Sejak Undang-undang Nomor 31 Tahun 1999 tentang Pemberantasan Tindak Pidana Konupsi (Lembaran Negara Republik Indonesia Tahun 1999 Nomor 140, Tambahnan lLembaran Negara Republik Indonesia Nomor 3874) diundangkan, terdapat berbagai interpretasi atau penafsiran yang berkembang di masyarakat lkhususmya mengenai penerapan Undang-undang tersebut terhadap tindak pidana korupsi yang terjadi sebelum Undang-undang Nomor 31 Tahun 1999 diundangkan. Hal ini disebabkan Pasal 44 Undang-undang tersebut monyatakan bahwa Undangundang Nomor 3 Tahun 1971 tentang Pemberantasan Timdak Pidana Konupsi dinyatakan tidak berlaku sejak Undang-undang $\mathbb{N}$ omor 31 Tahun 1999 diundangkan, sehingga timbul suatu anggapan adanya kekcosongan laukum untuk memproses tindak pidana korupsi yang terjadi sebeluw berlakunya Undang-undang Nomor 31 Tahun 1999\%.

${ }^{3}$ Bagir Manan, Harian Republika, Kamis 7 September 2000. 
Atas dasar uraian di atas maka sejak tanggal 21 Nopember 2001, saat diundangkannya Undang-undang Nomor 20 tahun 2001, berlakulah dua ketentuan pidana pembayaran uang pengganti, yaitu:

1. Pasal 34 c Undang-undang Nomor 3 Tahun 1971 bagi tindak pidana korupsi yang terjadi sebelum tanggal 16 Agustus 1999. Ketentuan ini akan berlaku delapan belas tahun lagi setelah tanggal 15 Agustus 1999 sebab menurut Pasal 28 Undang-undang Nomor 3 Tahun 1971 ancaman pidana penjara bagi pelaku tindak pidana korupsi maksimum seumur hidup sehingga daluarsa penuntutan pidana atas dasar Pasal 78 ayat (1) ke-4 KUHP adalah delapan belas tahun.

2. Pasal 18 ayat (1) b jo ayat (2) jo ayat (3) Undang-undang Nomor 31 Tahun 1999.

\section{Perkembangan Konstruksi Hukum Tentang Pidana Pembayaran Uang Pengganti Dari Hukum Pidana ke Hukum Perdata}

Apabila diperhatikan pengaturan pidana pembayaran uang pengganti sebagaimana telah diuraikan di atas maka pada awalnya pidana pembayaran uang pengganti dikonstruksikan sebagai bagian dari aturan hukum pidana. Hal ini tampak dalam:

a. Pasal 25 Peraturan Penguasa Militer Nomor Prt/PM/06/1957 diatur pada bagian VI tentang ketentuan-ketentuan pidana;

b. Pasal 40 ayat (3) Peraturan Penguasa Perang Pusat Nomor Prt/Peperpu/013/1958 yang dikeluarkan oleh Kepala Staf Angkatan Darat ditempatkan pada bagian IX tentang aturan-aturan pidana;

c. Pasal 40 ayat (3) Surat Keputusan Kepala Staf Angkatan Laut Nomor Z.1/1/7 tahun 1958 ditempatkan pada bagian IX tentang aturan-aturan pidana;

d. Pasal 16 ayat (3) Undang-undang Nomor 24 Prp. tahun 1960 ditempatkan pada Bab V tentang aturan-aturan pidana;

e. Pasal 34 c Undang-undang Nomor 3 tahun 1971 ditempatkan pada Bab $\mathrm{V}$ tentang ketentuan-ketentuan pidana;

f. Pasal 18 ayat (1) b jo ayat (2) jo ayat (3) Undang-undang Nomor 31 tahun 1999 ditempatkan pada Bab II tentang tindak pidana korupsi.

Berdasarkan aturan tersebut maka jelaslah bahwa pidana pembayaran uang pengganti semula merupakan bagian dari hukum pidana atau dikonstruksikan sebagai hukum pidana. Akan tetapi kemudian berkembang menjadi bagian dari hukum perdata. Hal ini antara lain terlihat dalam: 
a. Fatwa Mahkamah Agung Republik Indonesia Nomor 37/T4/88/ 66/Pid tanggal 12 Januari 1988 perihal fatwa mengenai eksekusi terhadap hukuman pembayaran uang pengganti (Pasal 34 Sub c U.U. Nomor 3 tahun 1971) dikonstruksikan sebagai hutang sehingga dengan demikian menjadi bagian dari hukum perdata atau masuk ruang lingkup hukum perdata. Bunyi fatwa itu antara lain "Dan karena hakekatnya pembayaran uang pengganti adalah merupakan hutang yang harus dilunasi terpidana kepada Negara, hutang tersebut sewaktu-waktu masih dapat ditagihkan melalui gugatan perdata di pengadilan yakni seandainya dalam pelaksanaan kali ini jumlah barang-barang yang dimiliki terpidana sudah tidak mencukupi lagi”.

b. Surat Edaran Mahkamah Agung Nomor 4 Tahun 1988 tanggal 7 Juli 1988 kepada Seluruh Ketua Pengadilan Tinggi dan Ketua Pengadilan Negeri di Indonesia tentang Eksekusi Terhadap hukuman Pembayaran Uang Pengganti (Pasal 34 Sub c U.U. Nomor 3 tahun 1971). Angka 3 Surat Edaran tersebut berbunyi, "Baru apabila seandainya dalam pelaksanaan kali ini jumlah barang-barang yang dimiliki oleh terpidana sudah tidak mencukupi lagi, sisanya apabila masih akan ditagihkan oleh Kejaksaan pada lain kesempatan harus diajukan melalui gugatan perdata di pengadilan".

c. Surat Edaran Jaksa Agung Republik Indonesia Nomor: SE004/J.A/8/1988 tanggal 5 Agustus 1988 tentang Pelaksanaan Pidana Tambahan Pembayaran Uang Pengganti (Pasal 34 Sub c Undangundang Nomor 3 tahun 1971). Angka 3 b berbunyi, "Seandainya dengan pelaksanaan kali ini, jumlah barang-barang yang dimiliki oleh terpidana juga tidak mencukupi lagi, kekurangan yang masih ada, agar ditagih melalui gugatan perdata".

Pertanyaan, tepatkah mengkonstruksikan pidana pembayaran uang pengganti sebagai hutang? Dr. Andi Hamzah, S.H. berpendapat, "Kalau kita perhatikan fatwa Mahkamah Agung RI yang menganggap uang pengganti sebagai hutang yang harus dilunasi terpidana kepada Negara, dan oleh karenaya sewaktu-waktu masih dapat ditagih melalui gugatan perdata, maka itu berarti suatu langkah mundur dari hakikat uang pengganti itu sebagai pidana tambahan, yang mestinya dapat dipaksakan pembayarannya". ${ }^{4}$ Pidana pembayaran uang pengganti yang sampai saat ini merupakan pidana

4 Andi Hamzah, "Perkembangan Hukum Pidana Khusus", Cetakan Pertama, (Jakarta: PT. Rineka Cipta, 1991), hal. 14. 
tambahan memang bernada perdata. ${ }^{5}$ "Oleh sebab itu ketentuan uang pengganti sebaiknya disamakan ketentuannya dengan pelaksanaan dalam hukum perdata. Sehingga uang pengganti merupakan jumlah terhutang dari terdakwa kepada negara". 6

Fatwa Mahakamah Agung Republik Indonesia yang mengkonstruksikan uang pengganti sebagai hutang dapat diterima. Akan tetapi adalah tidak tepat untuk memperoleh sisa uang pengganti yang belum lunas harus melalui gugatan perdata ke pengadilan. Penagihan kepada terpidana cukup atas dasar keputusan pidana yang menghukum terpidana untuk membayar uang pengganti sampai lunas. Jadi merupakan bagian dari eksekusi keputusan pidana yang belum tuntas, sehingga tidak perlu ada gugatan perdata lagi untuk menuntut terpidana melunasi hutang yang berasal dari pidana pembayaran uang pengganti tersebut. Jika fatwa Mahkamah Agung Republik Indonesia Nomor 37/T4/88/66/Pid tanggal 12 Januari 1988 tetap dipertahankan dan dilaksanakan maka alangkah panjangnya jalan yang harus ditempuh, yakni melalui gugatan perdata. Betapa banyaknya biaya, tenaga dan waktu yang tersita. Belum lagi sulitnya masyarakat untuk memonitor apakah negara yang diwakili oleh Jaksa telah atau belum mengajukan gugatan perdata terhadap para terpidana yang belum melunasi hutang yang berasal dari pidana pembayaran uang pengganti. Jangan-jangan negara juga lupa menuntutnya secara perdata karena banyaknya kasus serupa dan tugas-tugas lainnya. Tidak tertutup kemungkinan negara tidak menggugat hutang tersebut karena ada main mata antara terpidana dengan oknum aparatur negara, dalam hal ini oknum jaksa, sehingga dalam rangka mengeksekusi putusan perkara korupsi muncul KKN (Korupsi Kolusi dan Nepotisme) baru. Suatu lingkaran yang tidak ada ujung pangkalnya dalam memberantas tindak pidana korupsi besar kemungkinannya akan terjadi.

Persoalan selanjutnya adalah mengenai besarnya pidana pembayaran uang pengganti. Semua aturan yang ada mengatakan bahwa besarnya pidana pembayaran uang pengganti sebanyak-banyaknya sama dengan harta benda yang diperoleh dari korupsi. Apabila ditafsirkan secara a contrario maka pidana pembayaran uang pengganti tidak harus sama dengan harta benda yang diperoleh dari korupsi. Jadi bisa kurang. Ini jelas keliru, sebab adalah seharusnya pidana pembayaran uang pengganti itu sama dengan nilai harta benda yang diperoleh dari korupsi. Hakikat dari pidana pembayaran uang

${ }^{5}$ Ibid, hal. 64.

${ }^{6}$ Loebby Loqman, "Bebarapa Ikhwal Di Dalam Undang-undang Nomor 3 Tahun 1971 Tentang Pemberantasan Tindak Pidana Korupsi”, (Jakarta: 1992), hal. 63. 
pengganti adalah kembalinya uang negara secara utuh sehingga negara tidak mengalami kerugian.

Berhubung karena pidana pembayaran uang pengganti itu berupa uang yang jumlahnya sebanyak-banyaknya sama dengan harta benda yang diperoleh dari tindak pidana korupsi maka pertanyaan yang muncul adalah bagaimana cara menilai harta benda yang diperoleh dari tindak pidana korupsi tersebut? Apakah dinilai berdasarkan nilai uang atau harga saat tindak pidana korupsi dilakukan atau atas dasar nilai ketika hakim menjatuhkan vonis? Pertanyaan itu penting karena nilai dari harta benda yang diperoleh dari tindak pidana korupsi itu dapat dikatakan selalu berubah. Akan tetapi, tidaklah mudah untuk menjawab pertanyaan-pertanyaan tersebut karena di dalam penjelasan peraturan tentang tindak pidana korupsi tidak bisa ditemukan jawabannya. Pendapat R. Wiyono, S.H. adalah benar bahwa karena nilai uang itu turun naik dan agar jumlah uang pengganti dapat lebih efektif untuk mengganti harta benda yang diperoleh terpidana dari tindak pidana korupsi, maka penilaian harta benda itu harus menurut nilai uang atau harga ketika keputusan dijatuhkan oleh hakim. ${ }^{7}$

Fatwa Mahkamah Agung Republik Indonesia Nomor 37/T4/88/66/Pid tanggal 12 Januari 1988 dan Surat Edaran Mahkamah Agung Republik Indonesia Nomor 4 tahun 1988 tanggal 7 Juli 1988 serta Surat Edaran Jaksa Agung Republik Indonesia Nomor: SE-004/J.A/8/1988 tanggal 5 Agustus 1988 dikeluarkan untuk eksekusi hukuman pembayaran uang pengganti yang diatur dalam Pasal 34 Sub c Undang-undang Nomor 3 tahun 1971. Sedangkan saat ini undang-undang yang berlaku untuk pemberantasan tindak pidana korupsi tidak hanya Undang-undang Nomor 3 tahun 1971, akan tetapi juga Undang-undang Nomor 31 tahun 1999 jo Undang-undang Nomor 20 tahun 2001.

Pertanyaan, apakah pidana pembayaran. uang pengganti yang dikonstruksikan sebagai hutang juga dapat diterapkan untuk menyelesaikan pidana uang pengganti yang dijatuhkan melalui Undang-undang Nomor 31 tahun 1999 jo Undang-undang Nomor 20 tahun 2001 ? Jawabannya bisa dapat dan bisa tidak dapat diterapkan. Dasar untuk menerapkan hutang kepada terpidana yang melakukan tindak pidana di bawah Undang-undang Nomor 31 tahun 1999 jo Undang-undang Nomor 20 tahun 2001 adalah penafsiran secara sistematis, yaitu penjabaran terhadap undang-undang yang terlebih dahulu ada dapat diterapkan terhadap undang-undang yang lahir belakangan dan secara substansi uang pengganti yang diatur dalam Undangundang Nomor 3 tahun 1971 adalah sama dengan yang diatur dalam Undang-

${ }^{7}$ R. Wiyono, "Tindak Pidana Korupsi Di Indonesia", Cetakan Ketiga, (Bandung: Alumni, 1986), hal. 81. 
undang Nomor 31 tahun 1999 jo Undang-undang Nomor 20 tahun 2001. Sedangkan dasar untuk mengatakan bahwa konstruksi hutang terhadap uang pengganti tidak bisa diterapkan ke dalam Undang-undang Nomor 31 tahun 1999 jo Undang-undang Nomor 20 tahun 2001 adalah karena fatwa Mahkamah Agung dan Surat Edaran Mahkamah Agung serta Surat Edaran Jaksa Agung tersebut di atas secara eksplisit menyebut Pasal 34 Sub c Undang-undang Nomor 3 tahun 1971, sehingga secara yuridis formal tidak bisa diterapkan.

Selanjutnya mari kita menunggu fatwa Mahakamah Agung Republik Indonesia yang baru atau yurisprudensi mengenai hal tersebut. Sebaiknya Mahkamah Agung Republik Indonesia secepatnya mengemukakan pendapat, baik melalui fatwa maupun yurisprudensi. Hal ini penting untuk menciptakan kepastian hukum. Sambil menunggu pendirian Mahkamah Agung dan menghindari kekosongan hukum serta atas dasar asas manfaat maka sebaiknya uang pengganti yang dikonstruksikan sebagai hutang terpidana kepada negara yang semula ditujukan terhadap Undang-undang Nomor 3 tahun 1971 juga diberlakukan terhadap terpidana yang dihukum atas dasar Undang-undang Nomor 31 tahun 1999 jo Undang-undang Nomor 20 tahun 2001.

\section{Gagasan Pembaharuan}

Saat ini Pidana Pembayaran Uang Pengganti diatur dalam Pasal $34 \mathrm{c}$ Undang-undang Nomor 3 Tahun 1971 yang berbunyi, "Pembayaran Uang Pengganti yang jumlahnya sebanyak-banyaknya sama dengan harta benda yang diperoleh dari korupsi." Dan Pasal 18 ayat (1) b jo ayat (3) Undangundang Nomor 31 Tahun 1999 jo Undang-undang Nomor 20 Tahun 2001, yang berbunyi:

- Pasal 18 ayat (1) b "pembayaran uang pengganti yang jumlahnya sebanyak-banyaknya sama dengan harta benda yang diperoleh dari tindak pidana korupsi".

- Pasal 18 (3), “dalam hal terpidana tidak mempunyai harta benda yang mencukupi untuk membayar uang pengganti sebagaiman dimaksud dalam ayat (1) huruf $b$, maka dipidana dengan pidana penjara yang lamanya tidak melebihi ancaman maksimum dari pidana pokoknya sesuai dengan ketentuan dalam undang-undang ini dan lamanya pidana tersebut sudah ditentukan dalam putusan pengadilan.

Tampaknya ketentuan pidana pembayaran uang pengganti yang diatur dalam Pasal 34 c Undang-undang Nomor 3 Tahun 1971 dan Pasal 18 
Undang-undang Nomor 31 Tahun 1999 jo Undang-undang Nomor 20 Tahun 2001 tidak efektif untuk memberantas tindak pidana korupsi maka oleh karena itu perlu digagas pemikiran baru untuk memberantas tindak pidana korupsi melalui pidana pembayaran uang pengganti sebagai terurai di bawah ini.

Mahkamah Agung Republik Indonesia telah melakukan pembaharuan hukum terhadap ketentuan pidana pembayaran uang pengganti melalui Fatwa No. 37/T4/88/66/Pid. yang dikeluarkan pada tanggal 12 Januari 1988. Pembaharuan tersebut adalah: mengkonstruksikan uang pengganti sebagai hutang terpidana kepada negara; bila uang pengganti belum lunas maka dapat ditagih melalui gugatan perdata ke pengadilan dan uang pengganti tidak dapat diganti dengan pidana kurungan.

Walaupun Mahkamah Agung Republik Indonesia sudah melakukan pembaharuan hukum, namun tindak pidana korupsi tetap merajalela. Banyak faktor penyebabnya, antara lain adalah karena pidana pembayaran uang pengganti tidak wajib dijatuhkan oleh hakim kepada terpidana dan aturan pidana pembayaran uang pengganti tidak jelas. Oleh karena itu, perlu digagas pembaharuan lebih lanjut.

"Persoalan korupsi dan menghadapinya memang terutama persoalan perundang-undangan yang dapat mengadakan suatu inofasi, akan tetapi ia pula didampingi oleh Ilmu Hukum dan Yurisprudensi - kedua-duanya diakui sebagai sumber hukum - yang dapat mengembangkannya dengan metoda arsenal interpretasi yang makin bertambah dan meluas. Maka, perundangundangan, Ilmu Hukum dan Yurisprudensi mempunyai kaitan-kaitan yang sulit dipisahkan satu sama lain. Tugas ilmiah adalah untuk mengadakan suatu pengembangan, pula yurisprudensi mengadakan suatu "uitbouw", kadangkadang melakukan penghalusan, yang kesemuanya itu dapat menjadi sumber inspirasi bagi perencanaan undang-undang kelak.",

Gagasan pembaharuan yang hendak dikemukakan antara lain adalah sebagai berikut:

1. Menjadikan pidana pembayaran uang pengganti sebagai pidana pokok dan wajib dijatuhkan kepada terpidana

Agar penegak hukum menuntut dan menjatuhkan pidana pembayaran uang pengganti, terpidana tidak bisa berusaha untuk menghindar, sehingga uang negara dapat kembali, maka pidana pembayaran uang pengganti harus dijadikan pidana pokok.

8 Oemar Seno Adji, "Hukum Pidana Pengembangan", Cet. Pertama, (Jakarta: Erlangga, 1985), hal. 262. 
Harta benda yang dibeli dengan uang korupsi kemudian disita dan dilelang guna membayar uang pengganti maka harga jualnya apabila dibandingkan dengan harga disaat dibeli, ada tiga kemungkinan, yaitu:

\section{a. Lebih mahal;}

Jika lebih mahal, maka jumlah yang dihitung sebagai pembayaran uang pengganti adalah harga saat harta benda itu dibeli. Selisih harga tersebut yang berupa kelebihan adalah menjadi hak negara, bukan keuntungan yang bisa dinikmati oleh terpidana. Harga saat dibeli adalah harga riil di pasar, tidak harga yang digelembungkan (mark up). Misalnya bila berupa tanah maka dasarnya adalah Nilai Jual Objek Pajak (NJOP) yang ditetapkan pemerintah pada saat dibeli. Hal ini perlu dikemukakan karena harga tersebut bisa disiasati dari awal oleh mereka yang berencana melakukan tindak pidana korupsi.

\section{b. Sama;}

Jika harganya sama maka tidak ada masalah.

c. Lebih murah;

Jika hasil pelalangan dari harta benda tersebut lebih murah dari harga ketika dibeli, maka yang dihitung adalah harga saat pelelangan. Jumlah kekurangan tersebut merupakan hutang terpidana.

2. Tiga hukuman pokok bagi terpidana

Saat ini dalam undang-undang tindak pidana korupsi hanya ada dua hukuman pokok dan itu pun ada yang dirumuskan secara alternatif. Untuk masa yang akan datang terpidana akan memperoleh tiga hukuman pokok sekaligus. Pidana pokok dirumuskan secara kumulatif, tidak alternatif. Rumusannya adalah, ... dipidana dengan pidana mati atau pidana penjara ... tahun dan membayar uang pengganti sebesar kerugian yang diderita oleh negara serta pidana denda sebanyak ... rupiah.

Pidana pembayaran uang pengganti menempati urutan kedua dari pidana pokok karena uang pengganti lebih utama dari denda. Tujuan pidana pembayaran uang pengganti adalah agar uang negara yang dikorupsi, kembali ke negara. Pidana denda tetap dipertahankan karena merupakan langkah untuk menutupi kerugian yang dialami negara oleh ulah terpidana. 
3. Diberlakukan "waris pidana" terhadap tindak pidana korupsi Yang dimaksud dengan "waris pidana" adalah apabila terpidana tidak mampu membayar uang pengganti semasa hidupnya, maka ahli warisnya wajib membayar uang pengganti tersebut dengan harta bendanya dan tidak dapat menolak.

Gagasan "waris pidana" ini jelas bertentangan dengan asas geenstraf zonder schuld (tiada pidana tanpa kesalahan). Asas ini mulai berkembang sejak tahun 1916 dan pertama kali dipakai oleh Hoge Raad (Mahkamah Agung) di negeri Belanda pada putusannya tanggal 14 Pebruari 1916 dalam menyelesaikan perkara susu yang dicampur air (water en melk - arrest). ${ }^{9}$ Inti kasus tersebut adalah di Amsterdam ada suatu peraturan daerah yang melarang pengusaha susu peras untuk mencapurnya dengan bahan lain dan apabila dilakukan maka akan dikenakan pidana. Pengusaha susu A mencampur susu dengan air tanpa sepengetahuan si pengantar susu dan dengan demikian pengantar susu melanggar ketentuan APV (Algemene Politie Verordering). ${ }^{10}$ Pengadilan Arrondissements rechtbank dalam pemeriksaan banding atas putusan Kantonrechter di putus bahwa si pengantar susu dibebaskan karena tidak tahu tentang pencampuran susu tersebut dan pengusaha $\mathrm{A}$ di pidana karena menyuruh berbuat (doen plegen). Pengusaha A mengajukan kasasi karena menurutnya si pengantar susu harus dipidana karena dalam peraturan daerah tidak mensyaratkan adanya unsur kesalahan. Hoge Raad menolak kasasi tersebut dan membenarkan keputusan banding karena si pengantar susu sama sekali tidak mempunyai kesalahan. Ditegaskan oleh Hoge Raad bahwa diperlakukannya asas tiada pidana tanpa kesalahan adalah berdasarkan rechtsgevoel atau rasa keadilan. ${ }^{11}$

Dasar untuk mengemukakan gagasan "waris pidana", antara lain adalah sebagai berikut:

9 J.M. van Bemmelen (2), "Hukum Pidana 1", Cet. pertama, (Bandung: Bina Cipta, 1984), hal. 143.

${ }^{10}$ D. Schaffmeister, N. Keijer dan E. PH. Sitorus, "Hukum Pidana", Cet. ke-1, (Yogyakarta: Liberty, 1995), hal. 100.

${ }^{11}$ Wirjono Prodjodikoro, "Asas-asas Hukum Pidana di Indonesia", Cetakan Kedua, (Jakarta - Bandung: Eresco, 1979), hal. 64-65. 
a. Asas lex specialis derogat legi generali

Tindak pidana korupsi diatur dalam undang-undang hukum pidana khusus. Salah satu ciri dari undang-undang hukum pidana khusus adalah terdapatnya penyimpangan asas dari undang-undang hukum pidana umum. Dasar hukumnya adalah Pasal 103 KUHP.

Khusus mengenai kesalahan, Pasal 32 ayat (2) RUU KUHP memungkinkan seseorang dapat dipertanggungjawabkan atas tindak pidana yang dilakukan oleh orang lain, jika ditentukan dalam suatu undang-undang.

b. Asas geennstraf zonder schuld tidak berlaku mutlak "Van Hattum meneliti benar-benar pertimbanganpertimbangan dari Hoge Raad dan berkesimpulan bahwa Hoge Raad tidak menolak adanya kemungkinan, bahwa Pembentuk undang-undang mengenai suatu tindak-pidana tertentu secara tegas menyimpang dari prinsip "tiada hukuman-pidana tanpa kesalahan". Dengan demikian prinsip ini menurut Hoge Raad tidak bersifat mutlak". ${ }^{12}$

c. Ajaran Vicarious liability

Menurut ajaran ini, pertanggungjawaban pidana dialihkan dari pelaku fisik kepada orang lain (manusia atau korporasi) karena ada hubungan antara pelaku fisik dengan orang yang dipertanggungjawaban itu. Ajaran ini disebut juga dengan imputed liability dan berasal dari sistem Anglo Amerika. ${ }^{13}$ Vicarious liability sering diartikan dengan pertanggungjawaban pengganti. ${ }^{14}$ "....seseorang dapat dipertanggungjawawbkan atas perbuatan salah orang lain, ialah dalam hal tindak pidana terhadap public nuisance (yaitu suatu perbuatan yang menyebabkan gangguan substansial

${ }^{12}$ Ibid., hal. 66.

13 Mardjono Reksodiputro, Tindak Pidana Korporasi Dan Pertangguang jawabannya Perubahan Wajah Pelaku Kejahatan di Indonesia, Pidato Dies Natalis ke-47 Perguruan Tinggi Ilmu Kepolisian Markas Besar Kepolisian Negara Republik Indonesia, 1993, hal. 14.

14 Barda Nawawi Arief, "Perbandingan Hukum Pidana", Cet. pertama, (Jakarta: Rajawali, 1990), hal. 33. 
terhadap penduduk atau meninbulkan bahaya terhadap kehidupan, kesehatan dan harta benda). ${ }^{15}$

Konsideran Undang-undang No. 20 tahun 2001 huruf a mengatakan bahwa tindak pidana korupsi terjadi secara meluas, tidak hanya merugikan keuangan negara tetapi telah merupakan pelanggaran terhadap hak-hak sosial dan ekonomi masyarakat secara luas, sehingga pemberantasannya harus dilakukan secara luar biasa. Oleh karena itu tepat apabila ajaran vicarious liability diterapkan untuk memberantas tindak pidana korupsi.

d. Kurang berfungsinya lembaga pengawas

Selama ini lembaga pengawas untuk tidak terjadinya penyelewengan uang negara begitu banyak. Antara lain: Badan Pemeriksa Keuangan; Badan Pengawasan Keuangan dan Pembangunan; Inspektorat Jenderal; Pengawasan Melekat; Tromol Pos 5000. Walaupun begitu banyak, akan tetapi tindak pidana korupsi tetap merajalela.

Apabila "waris pidana" diberlakukan, maka setiap ahli waris akan mengingatkan keluarganya untuk tidak melakukan tindak pidana korupsi, sebab apabila itu terjadi maka ia sebagai ahli waris juga akan bertanggungjawab. Jadi para ahli waris bertindak sebagai pengawas dari dalam keluarga dan jauh lebih efektif dari lembaga pengawas yang sudah ada. Kalau selama ini mungkin ada diantara ahli waris yang menyuruh keluarganya melakukan tindak pidana korupsi maka sekarang mereka akan mengingatkan dan melarangnya.

e. Ahli waris ikut menikmati

Mustahil kiranya apabila ahli waris tidak ikut menikmati hasil korupsi yang dilakukan koruptor. Adalah logis apabila ahli waris juga ikut bertanggungjawab karena mereka ikut menikmatinya.

f. Pembuktian yang sulit

Ada kemungkinan, ahli warislah yang menyuruh atau membujuk terpidana untuk melakukan tindak pidana korupsi. Apabila ini terjadi maka menurut Pasal 55 KUHP ahli waris tersebut juga sebagai pelaku tindak pidana korupsi. Akan 
tetapi untuk membuktikan keterlibatan ahli waris sangat sulit karena pelaku korupsi akan melindungi ahli warisnya. Oleh karena itu dengan gagasan "waris pidana", pelaku tindak pidana korupsi tidak bisa melindungi ahli warisnya.

g. Konstruksi hukum tentang pidana pembayaran uang pengganti adalah sebagai hutang

Bagi mereka yang tunduk kepada KUH Perdata yang menerima warisan secara mutlak, maka mereka berkewaajiban untuk melunasi hutang pewaris. Pelunasan tersebut tidak hanya diambil dari warisan yang ditinggalkan pewaris, tetapi juga dari harta benda ahli waris.

Sedangkan bagi mereka yang beragama Islam yang menerima Kompilasi Hukum Islam untuk menyelesaikan warisan, maka hutang terpidana wajib dilunasi oleh ahli waris sebatas warisan yang ditinggalkan.

Berdasarkan apa yang dikemukakan di atas dapat disimpulkan bahwa dasar dari "waris pidana" sudah ada. Tinggal meningkatkan menjadi kewajiban melunasi hutang terpidana dengan harta benda ahli waris, sekiranya warisan yang ditinggalkan terpidana tidak mencukupi untuk membayar hutang pewaris dan tidak dapat menolaknya.

4. Segera keluarkan Surat Edaran Mahkamah Agung Republik Indonesia tentang kewajiban hakim untuk menjatuhkan pidana pembayaran uang pengganti.

Sambil menunggu perubahan undang-undang tentang pemberantasan tindak pidana korupsi yang menjadikan uang pengganti sebagai hukuman pokok dan diterimanya gagasan "waris pidana", maka seharusnyalah Mahkamah Agung Republik Indonesia mengeluarkan Surat Edaran yang mewajibkan hakim menjatuhkan pidana uang pengganti. Dalam kenyataan selama ini, hakim tidak selalu menjatuhkan pidana pembayaran uang pengganti.

Jaksa Agung sudah mengeluarkan Surat Edaran yang mewajibkan jaksa menuntut pidana pembayaran uang pengganti. Surat Edaran ini akan siasia karena hakim tidak wajib menjatuhkan pidana pembayaran uang pengganti. Agar Surat Edaran Jaksa Agung tidak menjadi sia-sia, maka harus diikuti dengan Surat Edaran Mahkamah Agung yang mewajibkan hakim untuk menjatuhkan pidana pembayaran uang pengganti.

Apabila ada hakim yang tidak mau melaksanakan Surat Edaran Mahkamah Agung tersebut maka dikenakan sanksi berupa menunda promosinya dan bahkan dijadikan hakim non palu. Jika pemikiran ini diterima dan dilaksanakan, pidana pembayaran uang pengganti akan berfungsi sebagai senjata pamungkas dalam pemberantasan tindak 
pidana korupsi. Hal ini sangat mungkin dilaksanakan karena pengadilan sudah berada di bawah satu atap, sepenuhnya di bawah Mahkamah Agung.

Jika pemikiran tersebut di atas tidak diterima dan dilaksanakan, maka sudah pasti tindak pidana korupsi tetap merajalela. Pidana pembayaran uang pengganti akan dijadikan alat peras oleh oknum hakim kepada pelaku tindak pidana korupsi, akhirnya berubah fungsi sebagai sumber Korupsi Kolusi dan Nepotisme. Harapan menjadikan pengadilan sebagai benteng terakhir untuk menegakan hukum dan tempat pemberi keadilan tidak pernah akan terwujud.

\section{Penutup}

Mungkin pemikiran yang dikemukakan dalam tulisan ini akan menimbulkan pro dan kontra. Walaupun demikian semoga saja tulisan ini ada manfaatnya sebagai pemicu pemikiran selanjutnya yang lebih sempurna dalam pengembangan ilmu hukum, khususnya hukum pidana. 


\section{Daftar Pustaka}

Harian Republika. Kamis, 7 September, 2000.

Hamzah, Andi. Perkembangan Hukum Pidana Khusus, Cetakan Pertama, Jakarta: PT. Rineka Cipta, 1991.

Loqman Loeby. Beberapa Istilah di Dalam Undang-undang Nomor 3 Tahun 1971 Tentang Pemberantasan Tindak Pidana Korupsi, Jakarta: 1992.

Nawawi Arief, Barda. Perbandingan Hukum Pidana, Cetakan pertama, Jakarta: Rajawali, 1990.

Prodjodikoro, Wirjono. Asas-asas Hukum Pidana di Indonesia, Cetakan Kedua, Jakarta-Bandung: Eresco, 1979.

Reksodiputro, Mardjono. "Tindak Pidana Korporasi dan Pertanggungjawabannya Perubahan Wajah Pelaku Kejahatan di Indonesia", Pidato Dies Natalis ke-47 Perguruan Tinggi Ilmu Kepolisian Markas Besar Kepolisian Negara Republik Indonesia, 1993.

Schaffmeister, D,N. Keijen dan E.PH. Sitorus. Hukum Pidana, Cetakan ke-1, Yogyakarta: Liberty, 1995.

Seno Adji, Oemar. Hukum Pidana Pembangunan, Cetakan pertama, Jakarta: Erlangga, 19985.

Utrecht, E. Hukum Pidana II, Surabaya: Pustaka Tinta Mas, 1987.

Van Bemmelen, J.M. Hukum Pidana I, Cetakan pertama, Bandung: Bina Cipta, 1984.

Wiryono, R. TPK di Indonesia, Cetakan ketiga, Bandung: Alumni, 1986. 